\title{
Insular species of Neotropical freshwater crabs (Crustacea: Brachyura)
}

\author{
G. RODRÍGUEZ and B. LÓPEZ
}

Instituto Venezolano de Investigaciones Cientificas, Centro de Ecologia, Apartado 21827, Caracas 1020 A, Venezuela; e-mail: grodrigu@oikos,ivic.ve

(Accepted 13 May 2002)

One species of Trichodactylidae and four species of Pseudothelphusidae are present on continental islands in three areas of Central and South America. (1) Trinidad and Margarita Island have, in common with the Venezuelan mainland, the pseudothelphusid Eudaniela garmani (Rathbun, 1898); additionally, Trinidad shares with the mainland the trichodactylid Dilocarcinus dentatus (Randall, 1839). These disjunct distributions can be attributed to changes in sea level during the Quaternary, but the presence of the endemic pseudothelphusid Microthelphusa odaelkae (Bott, 1970) in Trinidad probably reflects an older connection with the continent. (2) A new species, Potamocarcinus roatensis, was found on Roatan Island, off the coast of Honduras. A cladistic analysis of the genus Potamocarcinus (H. Milne Edwards, 1853) revealed a close association of $P$. roatensis with $P$. magnus (Rathbun, 1896), a widely distributed Central American pseudothelphusid. Possibly both species originated in a pre-Quaternary vicariant event. (3) Another pseudothelphusid, Hypolobocera gorgonensis von Prahl, 1983, inhabits disjunct areas on Gorgona Island, off the Pacific coast of Colombia, and on the mainland of Ecuador, reflecting either a wider distribution before the last Holocene transgression or accidental dispersal through natural rafts.

KeYwORDS: Pseudothelphusidae, Trichodactylidae, freshwater crabs, island biogeography, phylogenetics.

\section{Introduction}

Insular studies have provided important insights on the interplay of process and pattern in biogeography (Lomolino, 2000). However, the distribution of many organisms, particularly birds, insects and vascular plants, is not very informative about palaeogeographic history because their dispersal methods allow them indiscriminately to penetrate physical barriers isolating oceanic and continental islands. Freshwater crabs, on the other hand, are useful geographical tools for testing dispersalist or vicariant hypotheses because the absence of free-swimming larvae rigorously restricts them to their natural habitats ( $\mathrm{Ng}$ and Rodriguez, 1995). Exceptionally, the adaptations that Pseudothelphusidae possess for air breathing could enable them to be transported by natural rafts (Rodriguez, 1986).

Journal of Notural Hitotory

ISSN $0022-2933$ print/ISSN $1464-5262$ online 02003 Taylor \& Francis Lto

http:/ www.tandf.co.uk/journals

DOI: $10.1080 / 00222930210155710$ 
Of the two Neotropical freshwater crab families, the Pseudothelphusidae, with more than 229 known species, have eight species on oceanic islands in the Caribbean, namely, seven species of Epilobocera Stimpson, 1860, in Cuba, Hispaniola and Puerto Rico (Rodríguez and Williams, 1995), and Guinotia dentata (Latreille, 1825) in the Lesser Antilles islands of Guadeloupe, Dominica, Martinique, St Lucia and St Vincent. The problems posed by these oceanic distributions have been dealt with by Rodríguez (1986).

The species of Pseudothelphusidae recorded from continental islands are Eudaniela garmani (Rathbun, 1898) from Trinidad and Margarita Island, off the coast of Venezuela, Microthelphusa odaelkae (Bott, 1970) from Trinidad, and Hypolobocera gorgonensis von Prahl, 1983, from Gorgona Island, off the Pacific coast of Colombia. The Trichodactylidae, comprising 44 species (Rodríguez, 1992), have only one representative on continental islands, Dilocarcinus dentatus (Randall, 1839) recorded from Trinidad.

The present contribution deals with the geographical distributions of the aforementioned species from land bridge islands, together with a new species of Pseudothelphusidae from Roatan Island, off the coast of Honduras. The materials recorded are deposited in the Museum of Natural History of Tulane University, New Orleans (TU), the Field Museum of Natural History, Chicago (FMNH) and the reference collection of the Instituto Venezolano de Investigaciones Cientificas, Caracas (IVIC). Other abbreviations used are $\mathrm{cl}=$ carapace length, $\mathrm{cb}=$ carapace breadth and $\mathrm{ch}=$ carapace height as measured from the sternum to the top of upper surface.

\section{Systematics}

Family TRICHODACTYLIDAE H. Milne Edwards, 1853

Genus Dilocarcinus H. Milne Edwards, 1853

Dilocarcinus dentatus (Randall, 1839)

\section{Material examined}

Mitan, near Nariva Swamp, Trinidad, 27 March 1980, coll. A. E. Esteves, five males, $\mathrm{cl} 29.1,30.8,31.5,31.8$ and $32.3 \mathrm{~mm}$, cb $36.4,37.5,39.6,39.9$ and $41.3 \mathrm{~mm}$ (IVIC 734). Hato Terecay, $16 \mathrm{~km} \mathrm{~N}$ of El Manteco, Bolivar State, Venezuela, 7 June 1977, coll. S. Gorzula, one male, cl $30.8 \mathrm{~mm}$, cb 37.3 (IVIC 720). Canto Onoto, near El Callao, Bolivar State, Venezuela, one male, cl $33.7 \mathrm{~mm}$, cb 41.7 (IVIC 722). Laguna Campoma, Sucre State, Venezuela, one male, $\mathrm{cl} 41.6 \mathrm{~mm}$, cb 51.8 (IVIC 732). Hato Piritu, Calabozo, Aragua State, Venezuela, coll. F. Tamayo, January 1963, one male, cl $31.2 \mathrm{~mm}$, cb $39.3 \mathrm{~mm}$ (IVIC 724). Naguanagua, Carabobo State, Venezuela, coll. F. Rumbos, 7 November 1965 , one male, cl $30.3 \mathrm{~mm}$, cb $39.6 \mathrm{~mm}$ (IVIC 729).

\section{Remarks}

Pretzmann (19680) described the subspecies Dilocarcinus dentatus trinidadensis based on a male (cl. $35 \mathrm{~mm}$ ) from Trinidad, for which he gives the following characters: carapace narrower, flatter; 10 blunt lateral teeth; fingers of larger chela slightly gaping; dactylus shorter; gonopod wider, more recurved; colour dark brown. We compared five male specimens from Mitan, near Nariva Swamp, Trinidad, with five male specimens from several different localities on the nearby mainland of 
Venezuela, recorded under Material examined, taking the degree of narrowness of the carapace as the ratio $\mathrm{cb} / \mathrm{cl}$, its degree of flatness as the ratio $\mathrm{cb} / \mathrm{ch}$, and the relative length of the dactylus as the proportion of the dactylus to the length of the ventral border of the chela (table 1). A larger variability of these characters was observed in Venezuelan specimens; the range of variation of Trinidad specimens was included within the range of variation of Venezuelan specimens. The number of lateral teeth is 10 in both groups, except for one mainland specimen which has nine on the left side, and a Trinidadian specimen which has 11 teeth on the right side. No differences could be noted in the morphology of gonopods in both groups. The colour of specimens (preserved in alcohol) is very variable, from grey to brown, as already observed by Rodríguez (1992).

Family Pseudothelphusidae Rathbun, 1893

Tribe Hypolobocerinl Pretzmann, 1971

Genus Hypolobocera Ortmann, 1897

Hypolobocera gorgonensis von Prahl, 1983.

Hypolobocera gorgonensis von Prahl, 1983: 105, figure 1; 1988: 181, figure 13.

Hypolobocera muisnensis Rodriguez and von Sternberg, 1998: 123, figure 8.

Material examined

Gorgona Island, Colombia, 22 August 1989, received from von Prahl, one male, cl $50.6 \mathrm{~mm}$, cb $83.0 \mathrm{~mm}$ (TU 6303). Gorgona Island, Pacific, Cauca Department, Colombia, 1 February 1962, one male, cl $43.2 \mathrm{~mm}$, cb $69.9 \mathrm{~mm}$, one male with broken carapace, cb $81.2 \mathrm{~mm}$, one female, cl $47.2 \mathrm{~mm}$, cb $76.4 \mathrm{~mm}$ (FMNH 3687). Estero Lojca More, Muisne Salima, Esmeraldas Province, Ecuador, 21 October 1988, coll. J. C. Vieira, one male holotype of Hypolobocera muisnensis, cl $31.1 \mathrm{~mm}$, cb $51.6 \mathrm{~mm}$ (IVIC 952). Estero El Caxero, La Concordia, Esmeraldas Province, Ecuador, 1 October 1988, coll. J. C. Vieira, one male, cl $20.7 \mathrm{~mm}$, cb $31.9 \mathrm{~mm}$ (IVIC 953). Same data, 8 October 1988, one male cl $24.2 \mathrm{~mm}$, cb $39.5 \mathrm{~mm}$ (IVIC 954). Estero Moncauve, Recinto Moncauve, Esmeraldas Province, Ecuador, 5 January 1988 , coll. J. C. Vieira, one male cl $24.2 \mathrm{~mm}$, cb $39.5 \mathrm{~mm}$ (IVIC 955).

\section{Remarks}

Hypolobocera gorgonensis belongs to a group of 10 species of Hypolobocera from Ecuador, in which the lateral lobe is very elongated, extending to approximately

Table 1. Comparison of male specimens of Dilocarcinus dentatus from mainland Venezuela and Trinidad. Venezuelan specimens are ordered following the list of localities under Material examined.

\begin{tabular}{lcccccc}
\hline & $\begin{array}{c}\text { Trinidad } \\
\mathrm{cb} / \mathrm{cl}\end{array}$ & $\begin{array}{c}\text { Venezuela } \\
\mathrm{cb} / \mathrm{cl}\end{array}$ & $\begin{array}{c}\text { Trinidad } \\
\mathrm{cb} / \mathrm{ch}\end{array}$ & $\begin{array}{c}\text { Venezuela } \\
\mathrm{cb} / \mathrm{ch}\end{array}$ & $\begin{array}{c}\text { Trinidad } \\
\text { dactylus/chela }\end{array}$ & $\begin{array}{c}\text { Venezuela } \\
\text { dactylus/chela }\end{array}$ \\
\hline & 1.22 & 1.21 & 2.00 & 1.92 & 0.59 & 0.55 \\
& 1.25 & 1.23 & 2.01 & 1.96 & 0.59 & 0.57 \\
& 1.25 & 1.24 & 2.04 & 1.99 & 0.59 & 0.62 \\
& 1.26 & 1.26 & 2.04 & 2.00 & 0.60 & 0.63 \\
Mean & 1.28 & 1.31 & 2.05 & 2.08 & 0.61 & 0.65 \\
SD & 1.25 & 1.25 & 2.03 & 1.99 & 0.60 & 0.60 \\
& 0.019 & 0.034 & 0.019 & 0.053 & 0.008 & 0.038 \\
\hline
\end{tabular}


one-third the total length of the gonopod, subtriangular or gently curved; the apex in distal view is elongated, with its lateral half either rounded and horseshoe-shaped, or triangular and ending in an acute spine directed upwards (Rodriguez and von Sternberg, 1998). One of these species, Hypolobocera muisnensis from Esmeraldas Province, Ecuador, cannot be distinguished from $H$. gorgonensis, although there are slight differences in the material available for both species, such as the $\mathrm{cb} / \mathrm{cl}$ ratio which is 1.63 in $H$. gorgonensis $(N=3)$ and 1.62 in $H$. muisnensis $(N=4)$; and the proportion exognath length/ischium length of endognath which is $0.32(N=2)$ in $H$. gorgonensis and slightly more, $0.38(N==4)$, in $H$. muisnensis. The gonopod morphology is similar, except that the distal margin of the lateral lobe of Hypolobocera gorgonensis is rounded, whereas in $H$. muisnensis it is angled, and that $H$. muisnensis presents in caudal view a distal slope toward the mesial margin not observed in $H$. gorgonensis. These differences can be regarded as intraspecific variations and consequently Hypolobocera muisnensis should be considered a junior synonym of $H$. gorgonensis, notwithstanding the noteworthy disjunction and isolation of the respective areas.

\section{Habitat}

Regarding the specimens collected on Gorgona Island (FMNH 3687), the collector F. Medem stated on the label that the species is 'abundant in all the brooks, also in their upper courses and in the small Laguna Cabrera. Eaten by the Spectacled Caiman, Caiman sclerops spp.'

Tribe Potamocarcinini Ortmann, 1897

Genus Potamocarcinus H. Milne Edwards, 1853

Potamocarcinus roatensis sp. nov. (figure 1A-H)

\section{Material examined}

Port Royal, Roatan Island, Honduras, 10 March 1979, coll. D. E. Keith, found dead in streambed, one male HoLOTYPE, cl $59.6 \mathrm{~mm}$, cb $98.4 \mathrm{~mm}$ (TU 6267); one immature male PARATYPE, cl $16.2 \mathrm{~mm}$, cb $25.1 \mathrm{~mm}, 17$ March 1979, coll. D. E. Keith (TU6268).

\section{Diagnosis}

First male gonopods expanded laterally at middle; apical part bearing two rounded lobes of equal extension, caudal one partially overlapping mesial one, mesial one folded over mesial side and continued toward mesial process; mesial process digitiform, directed mesially; apical cephalic surface with well-developed bifid tooth and shorter lower process, both pointing mesially; field of spines slit-like.

Male holotype description. Carapace 1.65 times as wide as long, with deep and wide cervical groove, curving posteriorly and reaching lateral margin. Anterolateral margin with small postorbital notch, another wider notch at level of cervical groove, seven papillae on margin between these two notches, rest of anterolateral margin covered by 29 small and unequal teeth. Postfrontal lobes well defined, delimited anteriorly by two small scars, median groove obsolete except for slight incision on upper margin of front. Surface of carapace in front of postfrontal lobe flat and inclined anteriorly. Upper margin of front straight in dorsal view, with ill-defined papillae; lower margin visible in dorsal view, with row of papillae, almost straight 

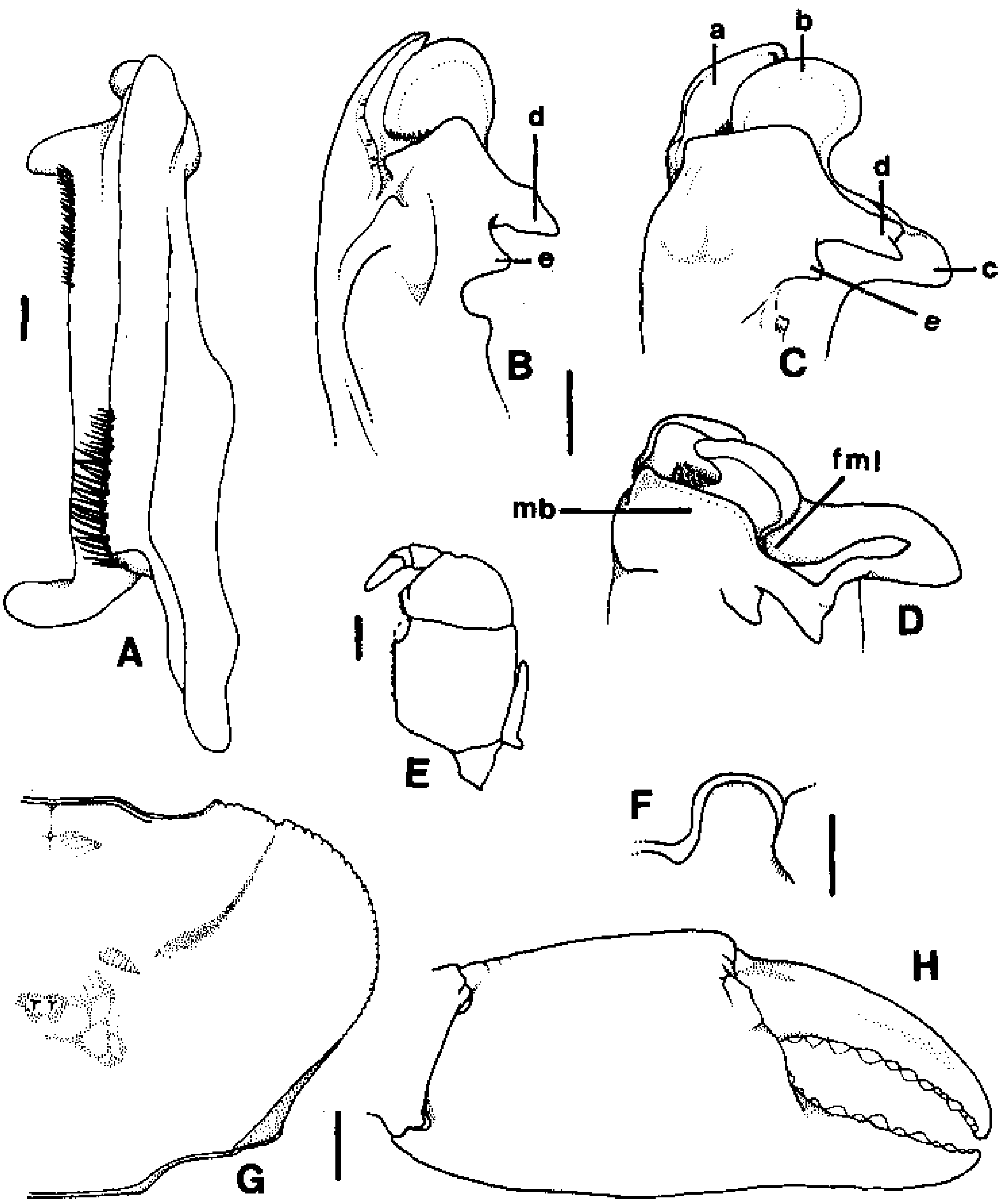

FIG. 1. Potamocarcinus roatensis, new species, holotype male from Port Royal, Roatan Island (TU 6267). (A) Left gonopod, caudal view; (B) apex, lateral view; (C) apex, cephalic view; (D) apex, distal view; (E) third maxilliped; (F) opening of left efferent channel; (G) dorsal view of right side of carapace; $(\mathbf{H})$ chela of largest cheliped, external view. a, Caudal lobe; b, mesial lobe; c, mesial process; d, cephalic tooth; e, cephalic process; fml, fold of mesial lobe; $\mathrm{mb}$, mesocephalic border. Scales: $(A-F)=1 \mathrm{~mm},(\mathrm{G}, \mathrm{H})=1 \mathrm{~cm}$.

in frontal view, space between upper and lower margin high. Surface of carapace covered by very small papillae, not visible to naked eye.

First pereiopod; heterochelous, right cheliped larger than left. Merus with three crests, external crest with round and scattered papillae, internal upper crest with row of tubercles decreasing in size proximally, internal lower crest with row of small teeth. Carpus with row of teeth on internal crest and prominent acute spine at 
middle. Inner and outer side of palms of both chelipeds smooth, lower margin with row of scattered small papillae. Palm of larger chela swollen, fingers gaping when closed, tips crossing; palm of smaller chela not swollen, fingers not gaping when closed. Third maxillipeds absent in holotype, in paratype (juvenile) third maxilliped with exognath 0.73 times length of ischium, merus of endognath curved with slight depression on distal part of external margin, orifice of efferent branchial channel open.

First male gonopods robust, expanded laterally at middle in caudal view (figure 1A). Apical part bearing two rounded lobes of equal extension (figure 1C: a, b), caudal one partially overlapping mesial one; mesial lobe folded over mesial side and continued toward mesial process (figure lD: fml). Mesial process digitiform, directed mesially. Cephalic surface with well-developed bifid tooth and lower shorter process, both pointing mesially. Field of spines slit-like, with mesocephalic border advanced (figure 1D: $\mathrm{mb}$ ).

\section{Remarks}

The gonopod of this species resembles that of Potamocarcinus magnus (Rathbun, 1896), but its mesial lobe is rounded, not subtriangular as in $P$. magnus, and has a lower apical tooth which is lacking in $P$. magnus.

\section{Other insular species examined}

Eudaniela garmani (Rathbun, 1898) is a well-defined species. No differential characters can be found between the populations within their general area of distribution in the Coastal Range of eastern Venezuela, Margarita Island and Trinidad Island (Rodriguez, 1982). The known altitudinal range of the species in the respective subareas are: mainland, $20-1500 \mathrm{~m}$; Margarita Island, $20-800 \mathrm{~m}$; Trinidad Island, $50-800 \mathrm{~m}$.

Microthelphusa odaelkae (Bott, 1970) is an endemic species, recorded only from its type locality in Cerro del Aripo, North Range, Trinidad, between 600 and $800 \mathrm{~m}$. The gonopod morphology of Microthelphusa odaelkae is very close to that of M. turumikiri Rodríguez, 1980 (see figures 115 and 116 in Rodriguez, 1982).

\section{Phylogenetic study of Potamocarcinus}

\section{Methodology for the analysis of Potamocarcinus}

The present cladistic analysis of Potamocarcinus includes all the species of this genus (table 2), with the exception of Potamocarcinus leptomelus Rodríguez and Hobbs, 1989, a taxon whose somatic and gonopodal characters considerably depart from others in the genus, due to its cave-dwelling adaptations, and $P$. armatus aequispinosus Pretzmann, 1971, which is a controversial species. Although this last is considered the type of the genus, its status is uncertain (Rodríguez, 1982), since the holotype is a female.

The strategy used in the cladistic analysis is similar to that employed in Rodriguez and Campos (1998). From 17 characters, selected for the analysis of Potamocarcinus (table 3), five were somatic characters which concern the shape of the front, postfrontal lobes, cervical groove, anterolateral margin of carapace, and proportion of the exognath of the third maxilliped. The other characters pertain to the morphology 
Table 2. List of species of Potamocarcinus used in the cladistic analysis with indication of the extension of the endognath of third maxilliped and the state of this character in parentheses. State $(0)$ corresponds to the outgroup that presents an endognath extension $>1$.

\begin{tabular}{lc}
\hline Species & Extension of endognath \\
\hline P. aspoekorum & $0.79(1)$ \\
$P$. zilchi & $0.91(1)$ \\
$P$. roatensis & $0.72(1)$ \\
P. richmondi & $0.52(2)$ \\
$P$. colombiensis & $0.52(2)$ \\
$P$. magnus & $0.59(2)$ \\
P. nicaraguensis & $0.53(2)$ \\
$P$. chajulensis & $0.40(2)$ \\
$P$. hartmanni & $0.50(2)$ \\
\hline
\end{tabular}

Table 3. Characters of Potamocarcinus compared.

1. Postfrontal lobes: (0) more or less defined; (1) absent and replaced by two small scars.

2. Cervical groove: (0) reaching margin of carapace; (1) not reaching margin

3. Antero-lateral margin between the orbit and cervical groove: (0) with small acute or papilliform teeth; (1) with spines; (2) smooth or with ill-defined papillae; (3) with prominent tuberculated teeth.

4. Anterolateral margin posterior to cervical groove: $(0)$ with sinall teeth; (1) armed with strong spines; (2) with ill-defined papillae.

5. Border of front: (0) with more or less defined tubercle; (1) with small spines.

6. Third maxilliped, ratio exognath to ischium of endognath: $(0)>1$; (1) approximately $1 ;(2)<1$.

7. Caudal Iobe of gonopod: (0) not exceeding the apex widely; (1) overreaching the apex widely.

8. Cephalic surface: (0) with a complex process; (1) with two elements (a hump +one sharp tooth); (2) with three elements, being all simple teeth; (3) with three elements including a bifid tooth; (4) with rudimentary processes or teeth.

9. Cephalic surface: $(0)$ with a patch of strong spines; (1) with a patch of weak spines; (2) without a patch of spines.

10. Cephalic surface with a hump or tooth below the bifid tooth: (0) absent; (1) present.

11. Hump below mesial process: (0) absent; (1) present and small; (2) present and prominent.

12. Margin of mesial lobe: (0) with strong spines; (1) with a crenulation; (2) smooth.

13. Mesial process: (0) incipient or not present; (1) like subtriangular plate; (2) like a narrow conic tooth; (3) jike sub-rounded tooth; (4) digitiform and bent; (5) like a broad conic tooth.

14. Mesial lobe: (0) not swollen at mesial side; (1) swollen at mesial side.

15. Mesial lobe: (0) not overreaching the apex; (1) exceeding slightly the apex; (2) exceeding widely the apex.

16. Mesial process: (0) rudimentary or not present; (1) acute; (2) blunt; (3) blunt and bent proximally.

17. Apex formed by: (0) three or more distinct lobes; (1) two distinct lobes; (3) two similar lobes.

of the first gonopods. The phylogenetic program used was PAUP version 4.0 beta 8 (Swofford, 1998) and option ALLTREES that guarantees the finding of all the most parsimonious trees. 
Table 4. Data matrix of 17 characters of Epilobocera sinuatifrons, Strengeriana risaraldensis and the species of Potamocarcinus.

\begin{tabular}{llllllllllllllllllll}
\hline Species & \multicolumn{11}{c}{ State of characters } \\
\hline E. sinuatifrons & 0 & 0 & 0 & 0 & 0 & 0 & 0 & 0 & 0 & 0 & 0 & 0 & 0 & 0 & 0 & 0 & 0 \\
S. risaraldensis & 0 & 1 & 0 & 0 & 0 & 0 & 0 & 0 & 1 & 0 & 0 & 2 & 0 & 0 & 2 & 0 & 0 \\
P. aspoekorum & 0 & 1 & 2 & 2 & 0 & 1 & 0 & 1 & 1 & 0 & 0 & 1 & 5 & 0 & 1 & 1 & 1 \\
$P$. zilchi & 1 & 1 & 2 & 0 & 0 & 1 & 0 & 1 & 1 & 0 & 0 & 1 & 5 & 0 & 2 & 1 & 1 \\
$P$. richmondi & 0 & 0 & 0 & 0 & 0 & 2 & 0 & 2 & 2 & 0 & 0 & 2 & 1 & 1 & 1 & 1 & 1 \\
$P$. colombiensis & 0 & 0 & 3 & 0 & 0 & 2 & 0 & 2 & 2 & 0 & 0 & 2 & 1 & 0 & 1 & 1 & 1 \\
$P$. magnus & 0 & 0 & 0 & 0 & 0 & 2 & 1 & 3 & 2 & 1 & 0 & 2 & 2 & 1 & 2 & 1 & 2 \\
$P$. roatensis & 0 & 0 & 0 & 0 & 0 & 1 & 1 & 3 & 2 & 1 & 0 & 2 & 3 & 0 & 2 & 2 & 2 \\
$P$. nicaraguensis & 0 & 0 & 3 & 1 & 0 & 2 & 1 & 3 & 2 & 0 & 2 & 2 & 4 & 0 & 2 & 3 & 2 \\
$P$. chajulensis & 1 & 1 & 1 & 1 & 1 & 2 & 1 & 4 & 2 & 0 & 1 & 2 & 2 & 0 & 2 & 1 & 2 \\
$P$. hartmanni & 1 & 1 & 1 & 1 & 0 & 2 & 1 & 4 & 2 & 0 & 1 & 2 & 2 & 0 & 2 & 1 & 2 \\
\hline
\end{tabular}

Homologies in the gonopodal processes of Potamocarcinus

One of the most significant homologies of these species regards the presence and shape of one or two apical lobes (figure 2F: a, b). In Potamocarcinus aspoekorum (Pretzmann, 1968a) and P. zilchi (Bott, 1956) only the mesial lobe is present; in $P$. aspoekorum it is placed transversally, but leaving exposed the field of spines, and in $P$. zilchi it is bent over the field of spines, forming a lid-like structure. In Potamocarcinus richmondi (Rathbun, 1893) and P. colombiensis von Prahl, 1987, the mesial lobe is poorly developed and the caudal lobe appears rudimentary. In the rest of the species both lobes are well developed; in Potamocarcinus magnus (Rathbun, 1896) the mesial lobe is inclined cephalically, a trend that continues in $P$. nicaraguensis (Rathbun, 1893) where the mesial lobe is applied over the field of spines (figure $2 \mathrm{H}: \mathrm{b}$ ).

A mesial process is present in all species of Potamocarcinus (figure 2), with specific differences in its shape and degree of development. In Potamocarcinus richmondi and $P$. colombiensis it forms a subtriangular plate directed meso-cephalically; it displays a progressive increase in $P$. aspoekorum and in $P$, zilchi, resembling in both species a broad conical tooth. In Potamocarcinus magnus, $P$. roatensis, $P$. chajulensis Alvarez and Villalobos, 1998 and $P$. hartmanni Pretzmann, 1975, this process appears like a narrow conical tooth, although in $P$. roatensis its apex is conspicuously blunt. In $P$. nicaraguensis it appears strongly modified as a finger-like projection, bent in the proximal direction and fused to the mesial lobe.

The cephalic surface of the first gonopods shows two elements in Potamocarcinus aspoekorum and $P$. zilchi, a sharp tooth and a spiny hump (figure $2 \mathrm{~A}, \mathrm{E}$ ). In the rest of the species the spiny hump is progressively obsolescent while the sharp tooth is divided into two separate elements. In Potamocarcinus richmondi and $P$. colombiensis (figure 2B, D: $d, d_{1}$ ) both elements are separated by a wide gap, but are close together in $P$. magnus, $P$. roatensis and $P$. nicaraguensis, forming a bifid tooth (figure $2 \mathrm{~F}, \mathrm{H}: \mathrm{d}, \mathrm{d}_{1}$ ). In Potamocarcinus hartmanni and $P$. chajulensis only rudimentary processes are observed on the cephalic surface.

\section{Outgroup selection}

The synapomorphies used to separate the genus Potamocarcinus are the following: (1) a mesial lobe that extends beyond the apex; (2) a well-developed mesial process; 


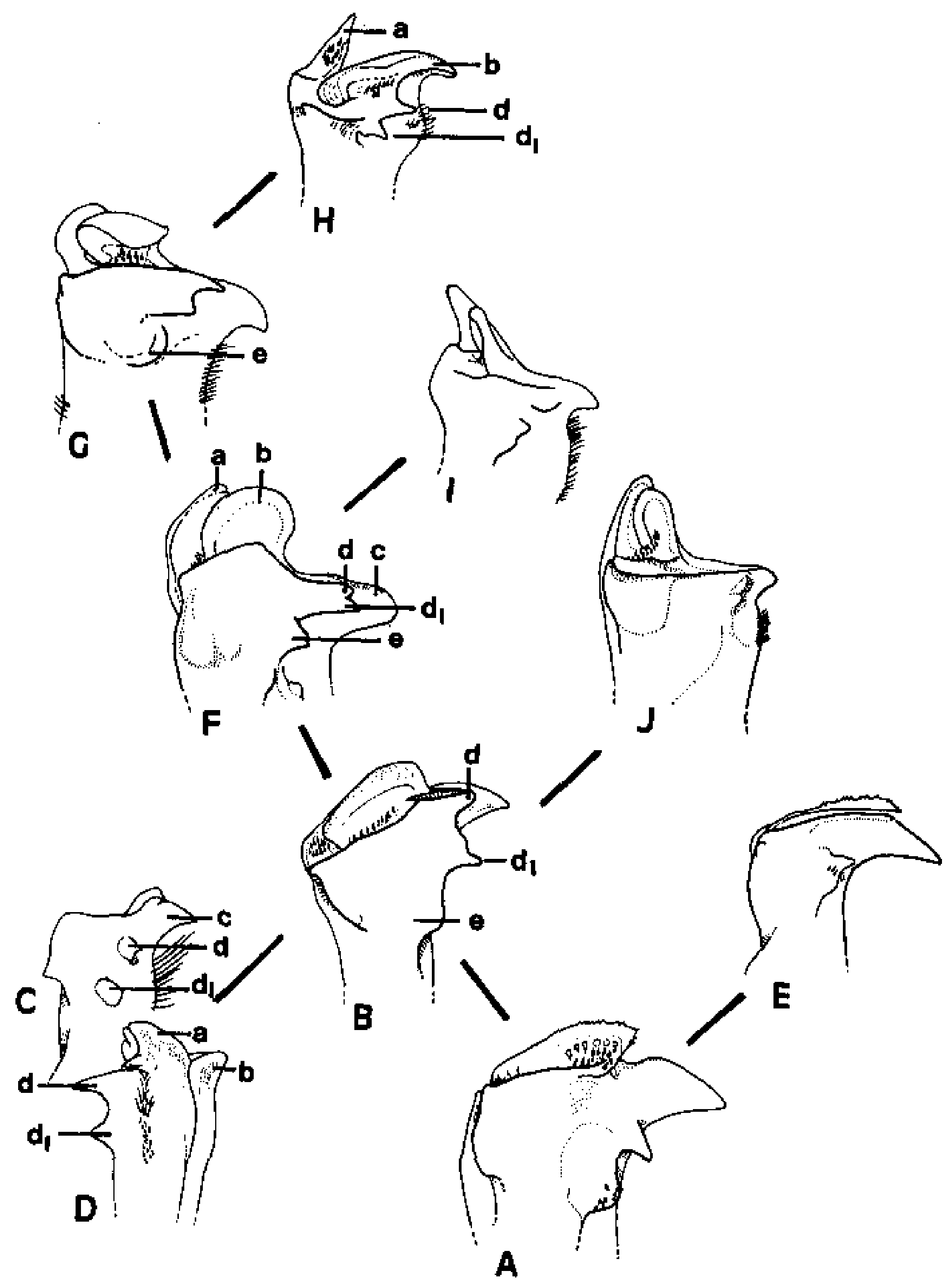

Fig. 2. Homologies in the gonopods of Potamocarcinus. (A) P. aspoekorum; (B) P. richmondi; (C) (D) P. colombiensis; (E) P. zilchi; (F) P. roatensis; (G) P. magnus; (H) $P$. nicaraguensis; (I) P. hartmanni; (J) P. chajulensis. a, Caudal lobe; b, mesial lobe; c, mesial process; $d, d_{1}$, cephalic teeth; e, cephalic process. All illustrations are in cephalic view, except (D) which is in mesial view.

(3) a cephalic process composed of a tooth and/or a hump; (4) a caudal lobe, that in some species can reach beyond the apex. The greatest similarity to the cup-shaped mesial lobe of Potamocarcinus is found in the more rudimentary mesial lobe of the species of the genus Strengeriana Pretzmann, 1971. Furthermore, in the case of 
Strengeriana risaraldensis Rodriguez and Campos, 1989, there is an incipient fingerlike projection on the mesial side, similar to the well-developed mesial process present in the genus Potamocarcinus. For these reasons $S$. risaraldensis can be considered as an outgroup for the polarization of characters.

A distinguishing feature of the Pseudothelphusidae is the reduction of the exognath in the third maxilliped (Rodriguez, 1986). This reduction, however, is not uniform in all species. The genera Epilobocera and Strengeriana have the exognath slightly larger than the ischium of the endognath, and one species of Epilobocera even has a rudimentary flagellum. The irreversible loss of the flagellum represents one of the basic synapomorphies of the Pseudothelphusidae, whereas its presence in Epilobocera represents the plesiomorphic condition of this character. Therefore the genus Epilobocera can be considered as approaching the ancestral condition of the family and, together with Strengeriana, will be used as a second out-group for the polarization of characters (table 4). Variations of this character within Potamocarcinus are presented in table 2.

\section{Results of the cladistic analysis}

The most parsimonious tree found has 42 steps and $\mathrm{CI}=0.82$ excluding uninformative characters (figure 3). According to this tree characters 1, 2, 3,6, 14 and 15 show homoplasic conditions. Character 5 is parsimony uninformative but defines

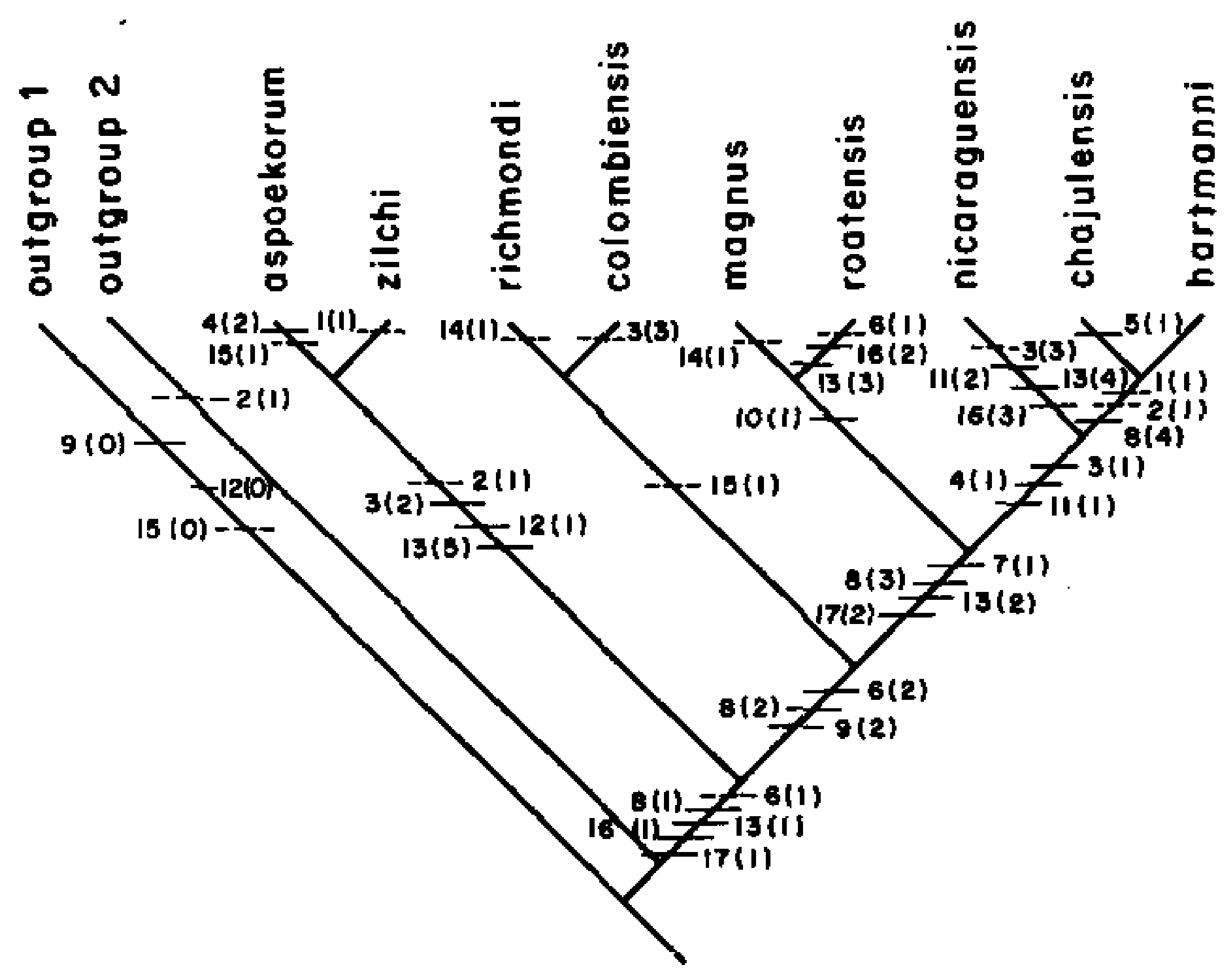

FIG. 3. Most parsimonious cladogram obtained for the species of Potamocarcinus, with indication of changes in character states. Outgroup 1, Epilobocera sinuatifrons; outgroup 2, Strengeriana risaraldensis. 
$P$. chajulensis as valid species. The tree starts with the sister pair Potamocarcinus aspoekorum-P. zilchi defined by characters $2(1), 3(2), 12(1)$ and 13(5). Then follows the cluster Potamocarcinus richmondi-P. colombiensis defined by character $15(1)$ and the rest of the species supported by characters $7(1), 8(3), 13(2)$ and $17(2)$. The cluster Potamocarcinus magnus-P. roatensis is defined by character 10(1). A final cluster, defined by characters $3(1), 4(1)$ and 11(1), splits into a branch leading to Potamocarcinus nicaraguensis, defined by characters 3(3), 11(2), 13(4) and 16(3), and another branch leading to the pair $P$, chajulensis $-P$. hartmanni, supported by characters $1(1), 2(1)$ and $8(4)$. The branch leading to Potamocarcinus hartmanni is not defined by any autapomorphy, and therefore is zero length.

\section{Continental insularity in Neotropical freshwater crabs}

Freshwater crabs appear in continental islands on three areas of Central and South America, and involve five species.

\section{Margarita and Trinidad Islands offshore of Venezuelan mainland}

Trinidad, Margarita Island and the mainland of Venezuela form an interrelated structural complex. The east-west trending Coastal Cordillera that extends parallel to the northern coast of Venezuela and eastward along the peninsula of Paria (as the Venezuela Eastern Range), crosses the strait which separates Venezuela from Trinidad, and forms the North Range in this island (figure 4A). Margarita Island, although situated geographically to the north of the backbone of the Coastal Cordillera, is usually related with this mountainous chain. It is generally accepted (Bellizia and Dengo, 1990) that there has been, since Tertiary times, a series of periodic submergences which brought about the break-up of the Coastal Cordillera, leaving as a remnant Margarita Island, and isolating Trinidad. At present a shallow platform, less than $60 \mathrm{~m}$ deep, connects Margarita Island to the northern coast of Paria, and Trinidad to the southern coast of the peninsula.

Dilocarcinus dentatus, a species widely distributed throughout South America, including many tributaries of the Orinoco River, has also a disjunct sub-area in Trinidad. The nearest mainland locality to Trinidad recorded for this species is in the Orinoco Delta, approximately $30 \mathrm{~km}$ from the Trinidad coast, at altitudes less than $2 \mathrm{~m}$ above sea level (López and Pereira, 1996).

Eudaniela garmani has disjunct sub-areas of distribution on the Venezuelan mainland, Trinidad and Margarita Island. The nearest recorded locality to Trinidad Island, on the Venezuela Mainland, for this species is at the eastern end of the Paria Penisula, approximately $30 \mathrm{~km}$ from the Trinidad North Range, whereas the distance of Margarita Island to the nearest locality of this species on the mainland (Cerro Turumiquiri? is $80 \mathrm{~km}$. Radiocarbon evidence has shown that this species has been present on the mainland for at least 5000 years b.p. (Rodriguez and Diaz, 1977).

Microthelphusa odaelkae is present at high altitude $(>800 \mathrm{~m})$ in the Trinidad North Range. The species of the genus closest to Microthelphusa odaelkae, both morphologically and geographically, is $M$. turumikiri Rodriguez, 1980, whose area of distribution is at the occidental end of the Venezuela Eastern Range, at $1500 \mathrm{~m}$ above sea level. The present distance between the areas of both species is $130 \mathrm{~km}$. The other species of the genus are found at considerable distances from Trinidad, in the Andes, Coastal Cordillera, Venezuelan Guiana and Surinam, all of them above $800 \mathrm{~m}$ altitude.

The submarine connections mentioned above emerged during the Pleistocene sea 


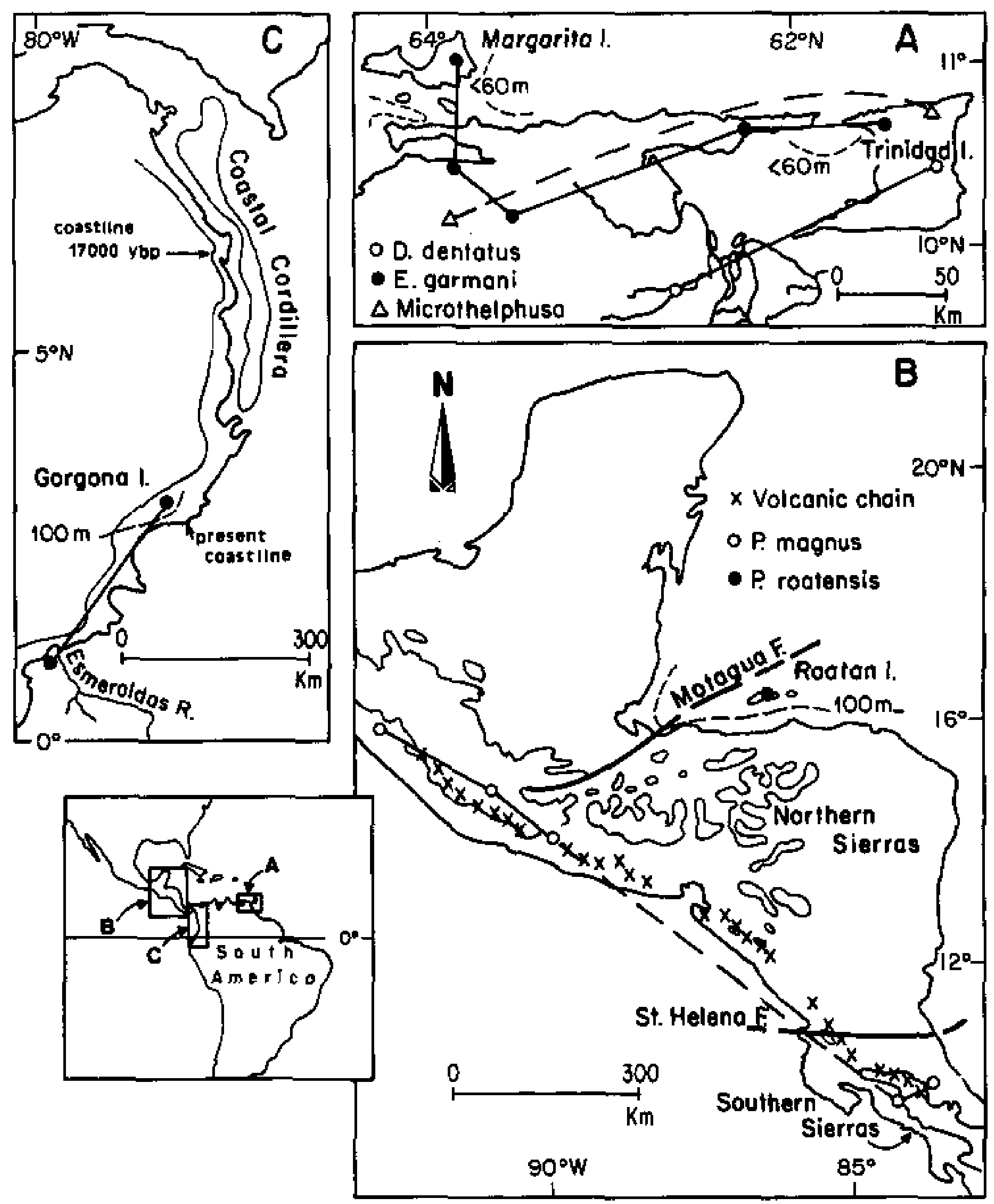

FIG. 4. Geographical setting of the Neotropical freshwater crabs from continental islands. (A) Dilocarcinus dentatus, Eudaniela garmani and Microthelphusa spp. in Trinidad, Margarita Island and the mainland of Venezuela; (B) Potamocarcinus roatensis and its sister species $P$, magnus in Roatan Island and the mainland of Central America; (C) Hypolobocera gorgonensis in Gorgona Island and the Pacific coast of South America.

lowering, and attained at least $61 \mathrm{~m}$ in this area, before the Holocene transgression that began approximately 11500 years b.p. A land connection during this period between the Orinoco Delta and the southeastern tip of Trinidad (Galeota Point) has been documented by Carr-Brown (1972). The presence of the Trinidadian subarea of distribution of Dilocarcinus dentatus can be understood in terms of this Pleistocene land bridge. Since Eudaniela garmani occurs at present down to low 
altitudes, its presence in the three sub-areas can be explained also by a Pleistocene expansion of the mainland sub-area across the Margarita-Venezuela and TrinidadVenezuela platforms.

The fragmented distributional pattern of the genus Microthelphusa and the altitudes at which the various species are found preclude the possibility of a Quaternary vicariant event for the origin of $M$. odaelkae, and rather points to an older Tertiary allopatric event.

\section{Northern coast of Honduras}

Two large areas of different tectonic and geologic structure have been recognized in Central America: namely, nuclear Central America, and the Isthmian Link from southern Nicaragua to northwestern Colombia. Nuclear Central America is almost all comprised within the Chortis Block defined to the north by the Motagua Fault in central Guatemala, and to the south by the Santa Helena Fault between Nicaragua and Costa Rica (figure 4B). The morphotectonic units within both areas are the Sierras of northern Central America, the Sierras of southern Central America and the Pacific volcanic Chain (Donnelly et al., 1990).

Roatan Island is part of the Bay Islands that sits on the Bonaca Ridge, north of the Honduras coast. The Bay Islands are probably a continuation of the mountain system of nuclear Central America (Donnelly et al., 1990), but this cannot be absolutely ascertained since Roatan Island has Cretaceous lithologies that are analogous to those of the Motagua Valley and the Cayman Ridge to the north-east.

As shown by our cladogram (figure 3), Potamocarcinus roatensis is a sister species of $P$. magnus. This latter species occupies two disjunct areas in both sections of Central America, the first in Chiapas State (Mexico), southern Guatemala and El Salvador, and a second one in Costa Rica (Rodriguez, 1982). In nuclear Central America Potamocarcinus magnus occurs along the Pacific volcanic chain, but it does not extend into the northern Sierras. In the Isthmian link Potamocarcinus magnus is restricted to Costa Rica in both the Pacific volcanic Chain and the southern Sierras.

Since Roatan Island is separated from the mainland by continuous depths between 200 and $1000 \mathrm{~m}$, a connection of both areas during minimal Quaternary sea level is precluded. The observed modern distributions of Potamocarcinus roatensis and the sister species $P$. magnus rather suggest a vicariant event of a widely distributed ancestor in pre-Quaternary times.

\section{Pacific coast of Colombia}

A tectonic trait of the northern Andes is a Coastal Cordillera, paralleling the coast, which originated during Eocene times. This cordillera can be followed as a separate unit from Panama to the Colombian Pacific coast, where it disappears at Cabo Corrientes. A small remnant, just touching the west coast of Ecuador at Esmeraldas, may form a missing link to this coastal belt. According to one theory Gorgona and Gorgonilla Islands represent an outcrop of this cordillera, $280 \mathrm{~km}$ to the south of Cabo Corrientes. Another theory holds that the islands are Cretaceous blocks from the Western Cordillera, which rotated north-east in relation to its original axis (Llinas et al, 1990).

Hypolobocera gorgonensis occupies two disjunct sub-areas of distribution on Gorgona Island and near the basin of the Esmeraldas River in Ecuador (figure 4C), separated by a sea distance of $300 \mathrm{~km}$. At present the island is separated from the coast of Colombia by depths between 80 and $100 \mathrm{~m}$, but a continuous connection 
with the Colombian and Ecuadorian coasts emerged during the last glaciation, 17000 years b.p., when the sea level dropped by approximately $120 \mathrm{~m}$ (figure $4 \mathrm{C}$ ). Alberico (1986) has shown that many vertebrate species from Gorgona Island are more closely related to species from Ecuador than to those of the nearby Colombian mainland. Thus a plausible hypothesis is that the geographical area of Hypolobocera gorgonensis before the Holocene transgression, which began approximately 10000 years b.p., comprised the two present disjunct areas and the then-emerged intervening lands. The morphological similarity between the insular and continental populations suggests a relatively recent date for the severance of the gene flow. Further study of this species using allozymes or other genetic markers would indicate whether the genetic similarity is as close as the morphological similarity suggests.

An alternative hypothesis is that Hypolobocera gorgonensis reached the island dispersed by rafts originating in the Esmeraldas River and transported northwards along the coast. The presence of numerous tree trunks on the west coast of the island, transported by currents, has been documented (Alberico, 1986). The main surface currents in this area have a northwesterly direction during January to March, with current speeds between 20 and $30 \mathrm{~cm} / \mathrm{s} \mathrm{(Forsbergh,} \mathrm{1969).} \mathrm{Given} \mathrm{these} \mathrm{current}$ characteristics, a raft could cover the distance between Esmeraldas, Ecuador, and Gorgona Island in 12-17 days, a passage not impossible for a group of crabs which possess pseudolungs for gas exchange with the fresh water contained in their branchial chambers (Rodriguez, 1986).

\section{Acknowledgements}

The authors thank Martha Campos for providing bathymetric maps and other valuable information on Gorgona Island, Celio Magalhaes for giving us access to material from the Field Museum of Natural History that had been sent to him for identification, and Héctor Suárez for his help in processing the manuscript.

\section{References}

Alberico, M., 1986, Biogeografía terrestre, in H. von Prahl and M. Alberico (eds) Isla de Gorgona (Bogotá: Biblioteca Banco Popular), pp. 223-244.

AlvareZ, F. and Villalobos, J. L., 1998, Six new species of fresh-water crabs (Brachyura: Pseudothelphusidae) from Chiapas, Mexico, Journal of Crustacean Biology, 18, 187-198.

Bellizia, A. and Dengo, G., 1990, The Caribbean mountain system, northern South America: a summary, in G. Dengo and J. E. Case (eds) The Geology of North America, Vol. H (The Caribbean Region, The Geological Society of America), pp. 167-175.

BotT, R., 1956, Dekapoden (Crustacea) aus El Salvador, 3. Süsswasserkrabben (Pseudothelphusa), Senckenbergiana Biologica, 36, 229-242.

BotT, R., 1970, Betrachtungen tiber die Entwicklungsgeschichte und Verbreitung der Sußßwasser-Krabben nach der Sammlung des Naturhistorischen Museums in Genf/ Schweiz, Revue Suisse de Zoologie, 77, fascicule 2 (24), 327-244.

CARr-Brown, B., 1972, The Holocene/Pleistocene contact in the offshore area east of Galeota Point, Trinidad, West Indies, Memorias de la VI Conferencia Geológica del Caribe, pp. 381-397.

Donnelly, T. W., Hornf, G. S., Finch, R. C. and López-Ramos, E., 1990, Northern Central America; The Maya and Chortis blocks, in G. Dengo and J. E. Case (eds) The Geology of North America, Vol. H (The Caribbean Region, The Geological Society of America), pp. 37-76.

ForseERGH, E. D., 1969, Estudio sobre la climatologia, oceanografía y pesquerías del Panama Bight, Boletin de la Comision Interamericana del Atim Tropical, 14, 154-170.

Latreille, P. A., 1825, Article 'Thelphuse', in Encyclopédie Méthodique, Histoire Naturelle, Entomologie, 10, 561-564. 
Llinas, R., Pinto, J., PeÑa, F, and Caro, F., 1990, Geología de las islas, in J. Aguirre and J. O. Rangel (eds) Biota y ecosistemas de Gorgona (Bogotá: Fondo FEN-Colombia), pp. 55-64.

LomoLJNo, M. V., 2000, A call for a new paradigm of island biogeography, Global Ecology and Biogeography, 9, 1-6.

López, B. and PEREIRA, G., 1996, Inventory of the decapod crustaceans of the high and middle Orinoco Delta, Venezuela, Acta Biologica Venezuelica, 16, 45-64.

Milne Edwards, H., 1853, Memoire sur la famille des Ocypodiens, Annales des Sciences Naturelles, Zoologie, 3e série, 20, 163-228.

NG, P. K. L. and RodRíGuez, G., 1995, Freshwater crabs as poor zoogeographical indicators: a critique of Banarescu (1986), Crustaceana, 68, 633-645.

OrtmanN, A., 1897, Carcinologische Studien, Zoologische Jahrbücher, Abtheiling für Systematik, Geographie und Biologie der Thiere, 10, 258-372.

PRAHL, H. voN, 1983, Hypolobocera gorgonensis (Crustacea: Brachyura: Pseudothelphusidae) un nuevo cangrejo de agua dulce de la Isla de Gorgona, Colombia, Cespedesia, 45/46, 105-110.

PRAHL, H. voN, 1987, Potamocarcinus colombiensis sp. nov.: un nuevo cangrejo de agua dulce (Decap. Brach. Pseudothelphusidae) de la Serrania Costera del Baudo, Colombia, Revista de Biologia Tropical, 35, 131-133.

PRAHL, H. voN, 1988, Fresh-water crabs (Crustacea: Brachyura: Pseudothelphusidae) of the Pacific drainage of Colombia, Zoologische Jahrbücher, Abtheilung fiur Systematik, Geographie und Biologie der Thiere, 115, 171-186.

PretzmanN, G., 1968a, Neue Sudamerikanische Sußwasserkrabben der Gatung Pseudothelphusa, Entomologisches Nachrichtenblatt (Vienna), 15(1), 1-15.

PretzmanN, G., 1968b, Die Familie Trichodactylidae (Milne Edwards 1853) Smith (vorläufige Mitteilung), Entomologischse Nachrichtenblatt (Vienna), 15(7/8), 70-76.

PretzManN, G., 1971, Fortschritte in der Klassifizierung der Pseudothelphusidae, Sitzungsberichten der Österreichischen Akademie der Wissenschaften. Mathematisch Naturwissenschaftliche Klasse, (1)179 (1-4), 15-24.

PretzmanN, G., 1975, Die bedornten Arten der Gattung Potamocarcinus Milne Edwards, 1853, Annalen des Naturhistorischen Musetums (Vienna), 79, 615-621.

RANDALL, J. W., 1839 (1840), Catalogue of the Crustacea brought by Thomas Nuttall and J. K. Townsend, from the West Coast of North America and the Sandwich Islands, with descriptions of such species as are apparently new, among which are included several species of different localities, previously existing in the collection of the Academy, Jowrnal of the Academy of Natural Sciences of Philadelphia, 8, 106-147.

Rathbun, M. J., 1893, Descriptions of new species of American freshwater crabs, Proceedings of the United States National Musetum, 16, 649-661.

Rathbun, M. J., 1896, Descriptions of two species of fresh-water crabs from Costa Rica, Proceeding of the United States National Museum, 18(1071), 377-379.

RathBUN, M. J., 1898, A contribution to a knowledge of the fresh-water crabs of America. The Pseudothelphusinae, Proceedings of the United States National Musetur, 21, $507-537$.

Rodríguez, G., 1980, Description préliminaire de quelques espèces et genres nouveaux de crabes d'eaux douce de l'Amérique Tropicale, Bulletin du Muséum National d'Histoire Naturelle (Paris), (4) Serie 2, Section A3, 885-894.

Rodríguez, G., 1982, Les crabes d'eau douce d'Amérique. Famille des Pseudothelphusidae, Faune Tropicale, 22, 1-223.

RoDríguez, G., 1986, Centers of distribution of neotropical fresh-water crabs, in R. H. Gore and K. L. Heck (eds) Biogeography of the Crustacea, Crustacean Issues, 4, 51-67.

Rodkiguez, G., 1992, The freshwater crabs of America. Family Trichodactylidae and supplement to the family Pseudothephusidae, Faune Tropicale, 31, 1-192.

Rodríguez, G. and CAMPOS, M., 1989, Cladistic relationships of the fresh-water crabs of the tribe Strengerianini (Decapoda: Pseudothelphusidae) from the northern Andes, with comments on their biogeography and descriptions of new species, Journal of Crustacean Biology, 9, 141-156.

Rodríguez, G. and CAMPos, M., 1998, A cladistic revision of the genus Freditu (Crustacea: Decapoda: Pseudothelphusidae) and its significance to the biogeography of the Guianan lowlands, Joturnal of Natural History 32, 763-775. 
Ronkíguez, G. and Dfaz, H., 1977, Note sur quelques restes de crabes d'eau douce (Pseudothelphusidae) provenant d'un 'Kjokken-Moeding' du Venezuela, Crustaceana, 33, $107-108$.

Roprígukz, G. and HoBBs, Jr, H. H., 1989, Freshwater crabs associated with caves in Southern Mexico and Belize, with descriptions of three new species, Proceedings of the Biological Society of Washington, 102, 394-400.

Ropriguez, G. and SternerRg, R. von, 1998, A revision of the freshwater crabs of the family Pseudothelphusidae (Decapoda: Brachyura) from Ecuador, Proceedings of the Biological Society of Washington, 111, 110-139.

RonRiguez, G. and WiLliams, A. B., 1995, Epilolobocera wetherbeei, a new species of freshwater crab from Hispaniola, Proceedings of the Biological Society of Washington, 108, 76-83.

Stimpson, W., 1860, Notes on American Crustacea. II, Annals of the Lyceum of Natural History of New York, 7, 176-246.

SwOFFord, D. L., 1998, PAUP. Phylogenetics Analysis Using Parsimony, Version 4 (Sunderland, MA: Sinauer Associates). 